\title{
Richard Cory
}

Edwin Arlington Robinson

Cedarville University

Follow this and additional works at: https://digitalcommons.cedarville.edu/cedarvillereview

Part of the Poetry Commons

DigitalCommons@Cedarville provides a publication platform for fully open access journals, which means that all articles are available on the Internet to all users immediately upon publication. However, the opinions and sentiments expressed by the authors of articles published in our journals do not necessarily indicate the endorsement or reflect the views of DigitalCommons@Cedarville, the Centennial Library, or Cedarville University and its employees. The authors are solely responsible for the content of their work. Please address questions to dc@cedarville.edu.

\section{Recommended Citation}

Robinson, Edwin Arlington (1996) "Richard Cory," Cedarville Review. Vol. 1, Article 1.

Available at: https://digitalcommons.cedarville.edu/cedarvillereview/vol1/iss1/1 


\section{Richard Cory}

\section{Keywords}

Poetry

Creative Commons License

(c) (i) (9)

This work is licensed under a Creative Commons Attribution-Noncommercial-No Derivative Works 4.0 License. 


\section{Richard Cory}

Whenever Richard Cory went down town, We people on the pavement looked at him: He was a gentleman from sole to crown, Clean favored, and imperially slim.

And he was always quietly arrayed, And he was always human when he talked; But he still fluttered pulses when he said, "Good morning," and he glittered when he walked.

And he was rich-yes, richer than a kingAnd admirably schooled in every grace:

In fine, we thought that he was everything To make us wish that we were in his place.

So on we worked, and waited for the light, And went without the meat, and cursed the bread; And Richard Cory, one calm summer night, Went home and put a bullet through his head.

-- Edwin Arlington Robinson 